\title{
EVALUATION OF FIXATIVE SOLUTIONS FOR ULTRASTRUCTURAL ANALYSIS OF BROWN SPIDER Loxosceles intermedia (ARANEAE: SICARIIDAE) TISSUES
}

\author{
COSTA-AYUB, C. L. S., FARACO, C. D. and FREIRE, C. A. \\ Laboratório de Biologia do Desenvolvimento, Departamento de Biologia Celular, UFPR, \\ Centro Politécnico, CEP 81531-990, Curitiba, Paraná, Brazil \\ Correspondence to: Cristina Lúcia Sant'Ana Costa-Ayub, DEBIOGEM/Setor de Ciências Biológicas e da Saúde, \\ Universidade Estadual de Ponta Grossa, Avenida Carlos Cavalcanti, 4748, Ponta Grossa, Paraná, \\ CEP 84030-900, Brazil, e-mail: crayub@ convoy.com.br \\ Received April 15, 2005 - Accepted June 30, 2005 - Distributed November 1, 2006
}

(With 7 figures)

\begin{abstract}
In view of the widely varying compositions of fixative solutions used for studying spiders, five different fixative formulas were tested for fixing male brown-spider (Loxosceles intermedia) gonad tissues. The brown spider represents a public health problem in Curitiba (Paraná State, Brazil). Morphological study of its gonads may aid in understanding the reproductive strategies of this species, and possibly in developing a reproduction control program. The fixatives tested contained glutaraldehyde alone or combined with paraformaldehyde, and the buffers cacodylate or phosphate, with or without the addition of sucrose or sodium chloride as osmolytes. Those containing $2.5 \%$ glutaraldehyde and $2 \%$ paraformaldehyde in $100 \mathrm{mM}$ phosphate buffer with $200 \mathrm{mM}$ sucrose, or in $200 \mathrm{mM}$ sodium cacodylate, satisfactorily preserved mitochondria, the Golgi apparatus, and the membranes in general. These formulas were nearly isosmotic (439 $\mathrm{mOsm} / \mathrm{kg} \mathrm{H}_{2} \mathrm{O}$ and $455 \mathrm{mOsm} / \mathrm{kg} \mathrm{H}_{2} \mathrm{O}$ respectively) to brown spider hemolymph $(478 \mathrm{mOsm} / \mathrm{kg}$ $\mathrm{H}_{2} \mathrm{O}$ ). With respective to the fixative agents, a glutaraldehyde-paraformaldehyde combination resulted in optimal fixation of Loxosceles intermedia cells. For other species of spiders, hemolymph osmolality should be considered, but the fixative formulas cited above would also probably yield good results.
\end{abstract}

Keywords: brown spider tissues, fixative solutions, Loxosceles intermedia, testis, ultrastructure.

\section{RESUMO}

\section{Avaliação de soluções fixadoras para a análise ultra-estrutural dos tecidos da aranha marrom Loxosceles intermedia (Araneae: Sicariidae)}

Dada a variabilidade na composição de soluções fixadoras utilizadas em aranhas, cinco diferentes fixadores foram elaborados para a análise ultra-estrutural dos tecidos da aranha marrom Loxosceles intermedia. A aranha marrom representa um problema de saúde pública na cidade de Curitiba, e o estudo morfológico de suas gônadas pode auxiliar na compreensão de suas estratégias reprodutivas e, possivelmente, no desenvolvimento de um programa de controle da sua população. As fórmulas usadas continham glutaraldeído com ou sem paraformaldeído, tampão cacodilato ou fosfato, e $\mathrm{NaCl}$ ou sacarose como osmólitos. As soluções fixadoras compostas por $2.5 \%$ glutaraldeído e $2 \%$ paraformaldeído, em tampão fosfato com adição de sacarose ou em $200 \mathrm{mM}$ cacodilato de sódio, preservaram bem estruturas como mitocôndrias, aparelho de Golgi e membranas em geral. Os tampões são praticamente isosmóticos ( $439 \mathrm{mOsm} / \mathrm{kg} \mathrm{H}_{2} \mathrm{O}$ e $455 \mathrm{mOsm} / \mathrm{kg} \mathrm{H}_{2} \mathrm{O}$, respectivamente) à hemolinfa da aranha marrom $(478 \mathrm{mOsm} / \mathrm{kg}$ $\mathrm{H}_{2} \mathrm{O}$ ). Ainda, com relação aos agentes fixadores, a combinação do glutaraldeído e paraformaldeído levou a uma melhor preservação das células. Para outras espécies de aranhas, a osmolalidade da hemolinfa deve ser medida e considerada, mas as fórmulas acima citadas podem ser testadas, com chance de sucesso.

Palavras-chave: tecidos da aranha marrom, soluções fixadoras, Loxosceles intermedia, testículo, ultraestrutura. 


\section{INTRODUCTION}

The genus Loxosceles includes the most poisonous spiders in Brazil. In the urban environment of the city of Curitiba, capital of Paraná State, the brown spider L. intermedia Mello-Leitão - 1934 (Araneae, Sicariidae) (Platnick - 2004) is the most common species, specially in domestic habitats where - according to recent reports - it poses an increasing danger. The poison of $L$. intermedia acts proteolytically (Silveira et al., 2002), causing a local necrotic skin lesion, frequently with systemic effects that can be lethal (Gonçalves de Andrade et al., 2000). The study of L. intermedia reproduction and its morphological features by electron microscopy can promote better understanding this spider's biology and reproductive strategies. Furthermore, it should be useful in developing a reproduction control program. Considerable variation in composition of buffer and fixative solutions for studying spider tissues is found in ultrastructural studies in the literature. It is well known that a detailed analysis of any tissue or organ's ultrastructure requires optimal preservation of the material. Therefore, fixatives, buffer compositions and osmolality, and type of osmolytes should all be carefully considered before being selected.

This work reports treatment of male brownspider gonads: the tissue chosen, and the five different fixative solutions tested, all of which were of different osmolalities and buffer compositions.

\section{MATERIAL AND METHODS}

\section{Material analyzed}

Adult brown-spider (Loxosceles intermedia) males were donated by inhabitants Curitiba,

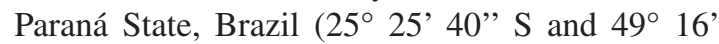
23 " W). The spiders were kept in small plastic vials in the laboratory, and twice a month received Tenebrium sp. larvae and water in a small, saturated cotton ball). A total of 15 adult male L. intermedia specimens were used, along with 3 spider testes fixed with each of the 5 different fixative solutions tested. Spider hemolymph was extracted from the cephalothorax at the point where the legs are inserted. Two hemolymph pools, each from 5-6 spiders, were obtained.

\section{Fixative solutions}

The compositions of the 5 fixative formulas tested appear in Table 1. In every case, the $\mathrm{pH}$ was 7.4. Fixative solutions (FS) were prepared with glutaraldehyde alone (FS 4) or glutaraldehyde plus paraformaldehyde. Glutaraldehyde was tested in two different concentrations (2\% in FS 1, and 2.5\% in FS 2 - 5). Phosphate (FS 1, 2, and 3) and sodium cacodylate (FS 4 and 5) were tested as buffers, and osmolytes tested were $\mathrm{NaCl}$ (FS 1) and sucrose (2). Phosphate buffer was first tested as an nontoxic alternative to cacodylate. Measured osmolality of the fixative solutions was $423-523 \mathrm{mOsm} / \mathrm{kg} \mathrm{H}_{2} \mathrm{O}$ above buffer osmolality, except for fixative 4 , in which the difference was $211 \mathrm{mOsm} / \mathrm{kg} \mathrm{H}_{2} \mathrm{O}$.

TABLE 1

Composition and osmolality of buffers and fixative solutions.

\begin{tabular}{|c|c|c|c|c|c|c|c|c|}
\hline \multirow{3}{*}{$\begin{array}{l}\text { Fixative } \\
\text { solutions }\end{array}$} & \multicolumn{6}{|c|}{ *Composition } & \multirow{2}{*}{\multicolumn{2}{|c|}{$\begin{array}{c}\text { Osmolality } \\
\left(\mathrm{mOsm} / \mathrm{kg} \mathrm{H}_{2} \mathrm{O}\right)\end{array}$}} \\
\hline & \multirow{2}{*}{$\begin{array}{c}\text { Gluta } \\
(\%)\end{array}$} & \multirow{2}{*}{$\begin{array}{l}\text { Paf } \\
(\%)\end{array}$} & \multicolumn{4}{|c|}{ Buffer (mM) } & & \\
\hline & & & PB & CACO & $\mathrm{NaCl}$ & SUC & Buffer & $\begin{array}{l}\text { Fixative } \\
\text { solution }\end{array}$ \\
\hline 1 & 2 & 2 & 100 & - & 50 & - & 302 & 725 \\
\hline 2 & 2.5 & 2 & 100 & - & - & 200 & 439 & 871 \\
\hline 3 & 2.5 & 2 & 200 & - & - & - & 453 & 976 \\
\hline 4 & 2.5 & - & - & 200 & - & - & 454 & 665 \\
\hline 5 & 2.5 & 2 & - & 200 & - & - & 454 & 899 \\
\hline
\end{tabular}

* Gluta = Glutaraldehyde; Paf = Paraformaldehyde; PB = Phosphate buffer CACO = Sodium cacodylate buffer; and SUC $=$ Sucrose. 


\section{Osmolality measurements}

Osmolality of the two hemolymph pools and of all fixative solutions and buffers was measured using a vapor pressure osmometer (VAPRO 5520, Wescor, USA). Each sample was measured in triplicate.

\section{Dissection, fixation, and embedding method}

Testes dissection, which took about $15 \mathrm{~min} /$ spider was done with the spider immersed in the fixative solution chosen. Fixation, including dissection, required $3 \mathrm{~h}$ and was done at $4{ }^{\circ} \mathrm{C}$, followed by several washings in the buffer being tested. Following post-fixation with $1 \%$ osmium tetroxide, prepared with the same buffer used in the primary fixative, samples were washed in distilled water, dehydrated in a graded series of ethanol and embedded in Spurr's resin, according to standard protocols.

\section{Sectioning, staining and analysis}

Ultrathin sections $(70 \mathrm{\eta m})$ were obtained using a Leica Ultracut ultramicrotome (UCT), and were contrasted with 5\% uranyl acetate for $30 \mathrm{~min}$, and for $10 \mathrm{~min}$ with Reynold's lead citrate. Sections were examined in a transmission electron microscope (TEM), jeol JEM-1200 EX II; electron micrographs were obtained with Gatan Digital Micrograph software for image acquisition. The analyses were done by comparing tissue preservation - particularly of the mitochondria, the Golgi apparatus, and the cellular membranes - based on the electron micrographs.

\section{RESULTS}

The mean osmolality of the two pools of brown spider hemolymph was $478 \mathrm{mOsm} / \mathrm{kg}$
$\mathrm{H}_{2} \mathrm{O}$. As described in Table 1 , buffer solution 1 (100 mM phosphate buffer plus $50 \mathrm{mM} \mathrm{NaCl}$ ) was hyposmotic to brown spider hemolymph. Buffer solution 2 (100 mM phosphate buffer plus $200 \mathrm{mM}$ sucrose) was slightly hyposmotic, and the others (solution 3: $200 \mathrm{mM}$ phosphate buffer, and solutions 4 and 5: $200 \mathrm{mM}$ sodium cacodylate) were nearly isosmotic to hemolymph osmolality.

Table 2 summarizes the results obtained with the five fixative solutions (FS). In the electron micrographs of the testes fixed with FS 1, the cells appeared swollen, despite the addition of $\mathrm{mM} \mathrm{NaCl}$ to the phosphate buffer. Mitochondria presently frequently swollen cristae (Fig. 1); the images of the Golgi apparatus were poorly defined.

The tissue treated with FS 2 presented clear indications of swelling and poor preservation, despite the addition of $200 \mathrm{mM}$ sucrose. The cells, however, displayed intact, much more clearly defined cytoplasmic membranes, and their mitochondria presented a less dense matrix and were better preserved than the membranes themselves. But cristae swelling was still evident (Figs. 2 and 5).

As for FS 3, the use of $200 \mathrm{mM}$ phosphate buffer resulted in completely dried out tissue, which fragmented when sectioned (Table 2).

With respect to FS 4, which contained $2.5 \%$ glutaraldehyde (without paraformaldehyde) and $200 \mathrm{mM}$ sodium cacodylate instead of phosphate, the result was slightly better tissue preservation, as compared to the results of all previous fixative solutions. Only occasional swelling was observed, and cells and organelles were generally well preserved (Figs. 3 and 6). However, this solution made the cytoplasm appear flocculated. The best result was obtained using FS 5, which contained

TABLE 2

General appearance of tissues of brown spider testes fixed with the five solutions tested.

\begin{tabular}{|c|c|c|c|c|}
\hline \multirow{2}{*}{ Fixative solution } & \multicolumn{4}{|c|}{ General aspect of the tissue } \\
\cline { 2 - 5 } & Cell preservation & Plasma membranes & Mitochondria & Golgi apparatus \\
\hline 1 & - & + & - & - \\
\hline 2 & - & ++ & + & ++ \\
\hline 3 & $*$ & $*$ & $*$ & $*$ \\
\hline 4 & + & ++ & + & ++ \\
\hline 5 & ++ & ++ & ++ & ++ \\
\hline
\end{tabular}

(-) non-preserved; $( \pm)$ poorly preserved; $(+)$ preserved; $(++)$ well preserved; and $(*)$ could not be analyzed due to very poor preservation. 

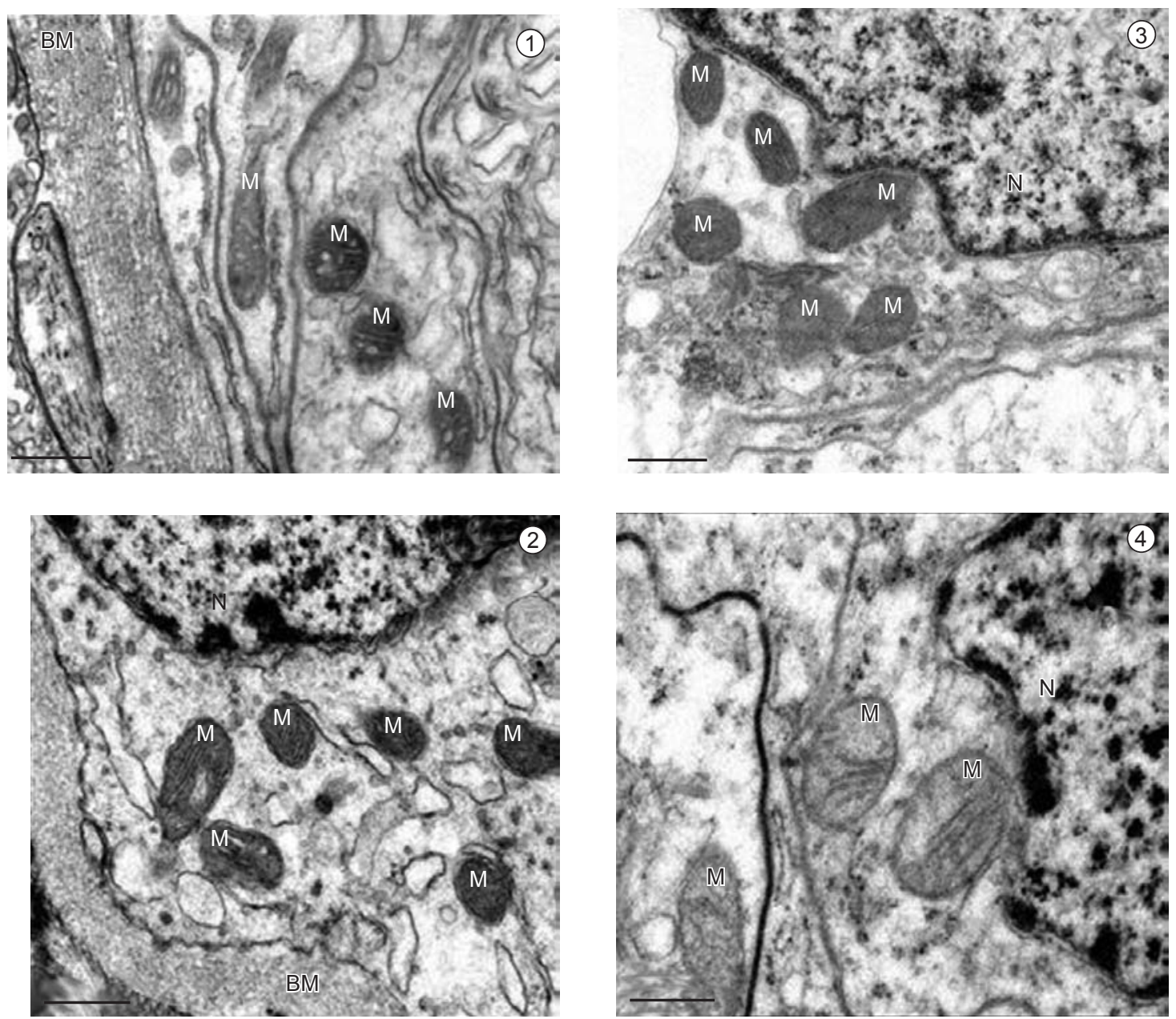

Fig. 1-4 - Transmission electron micrographs showing brown spider testes fixed with 1) FS 1;2) FS 2; 3) FS 4; and 4) FS 5. Scale bar: $0.5 \mu \mathrm{m}$. BM: basal membrane, M: mitochondria, $\mathrm{N}$ : nucleus.

$2.5 \%$ glutaraldehyde with the addition of $2 \%$ paraformaldehyde in $200 \mathrm{mM}$ sodium cacodylate buffer (Figs. 4 and 7). The tissue appeared uniform, and presented little swelling or tissue disruption; cell membranes were intact, mitochondria and the Golgi apparatus very well preserved, with a clear matrix, intact membranes, and only occasional swelling (Table 2).

\section{DISCUSSION}

This study recounts a search for a suitable buffer and fixative solution for ultrastructural study of Loxosceles intermedia using male gonad tissue. In the literature on spider ultrastructure, a wide variety exists in buffer and fixative solution composition. Solutions buffered with either phosphate (Suzuki \& Kondo, 1994; Suzuki, 1995; Michalik et al., 2004), or sodium cacodylate (Uhl, 2000) in different concentrations, with or without salt addition, have been used for various species of spiders.

In the present study, five different fixative formulae were prepared and tested, based on the formulas described in the above references, and modified in order to adapt them to brown spider hemolymph osmolality, which is $478 \mathrm{mOsm} / \mathrm{kg}$ $\mathrm{H}_{2} \mathrm{O}$ and within the $400-600 \mathrm{mOsm} / \mathrm{kg} \mathrm{H}_{2} \mathrm{O}$ range for spiders cited by Foelix (1996).

With respect to osmolality, buffer $1(100 \mathrm{mM}$ phosphate buffer plus $50 \mathrm{mM} \mathrm{NaCl}$ ) was not adequate, probably because it was hyposmotic 

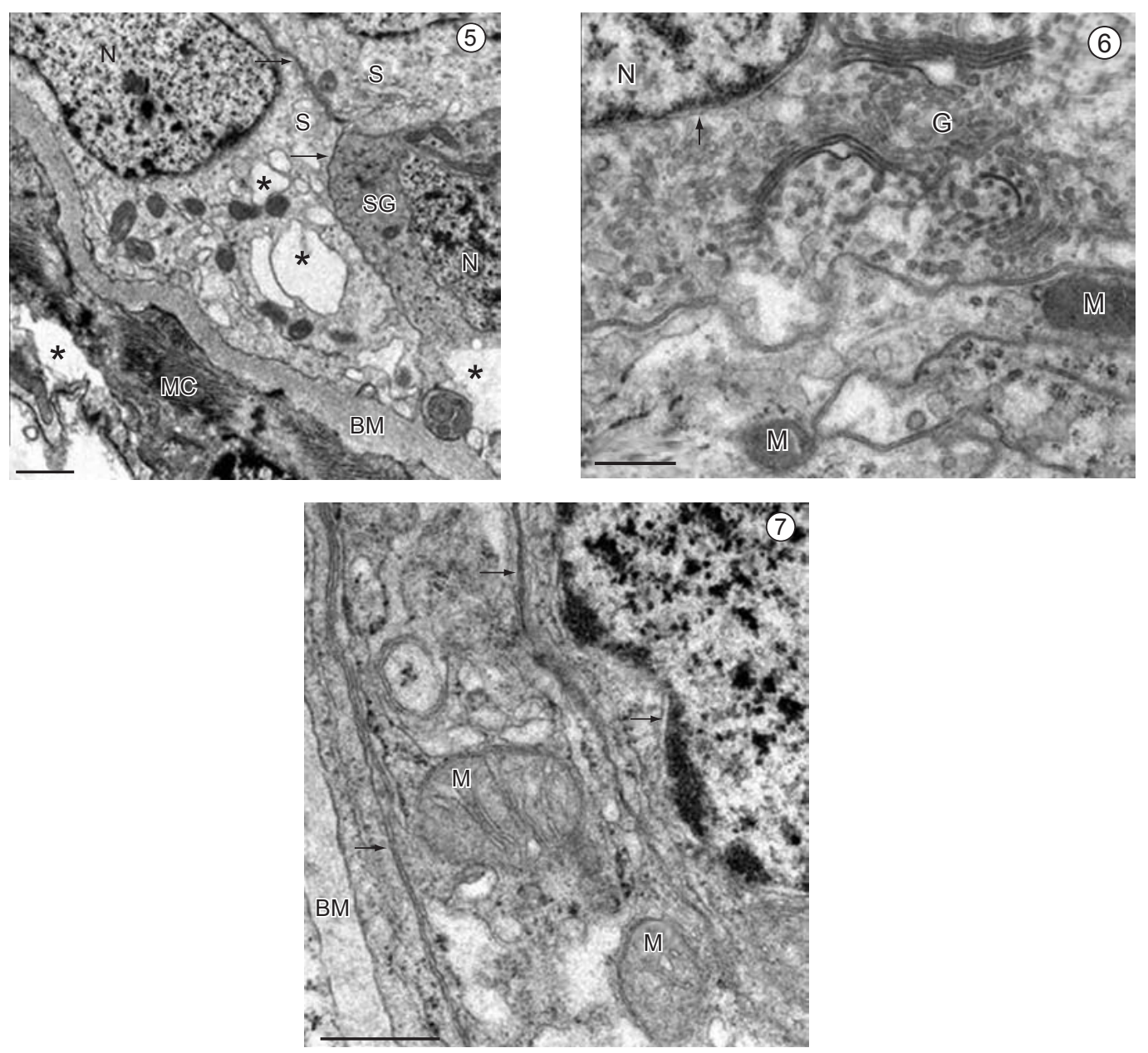

Fig. 5-7 - Transmission electron micrographs showing details of cells treated with FS 2, 4, and 5. 5) FS 2, showing poor cell preservation, with signs of swelling. Scale bar: $1.0 \mu \mathrm{m}$; 6) FS 4, scale bar: $0.5 \mu \mathrm{m}$; 7) FS 5, scale bar: $1.0 \mu \mathrm{m}$. (*) swelling points, BM: basal membrane; G: Golgi apparatus; M: mitochondria. MC: myoepithelial cell; N: nucleus; S: somatic cell; SG: spermatogonia. Black arrow: nuclear membrane; white arrow: cell membrane.

(302 $\mathrm{mOsm} / \mathrm{kgH}_{2} \mathrm{O}$ ) to the brown spiderhemolymph (Tables 1 and 2, Fig. 1). The other buffer solutions were nearly isosmotic to the hemolymph. However, not only is osmolality significant, but also the buffer and fixative solution composition (Hayat, 1970). An ionic osmolyte was used in $\mathrm{FS} 1(\mathrm{NaCl})$, and a non-ionic osmolyte in FS 2 (sucrose), which rendered the osmolality value $\left(439 \mathrm{mOsm} / \mathrm{kg} \mathrm{H}_{2} \mathrm{O}\right)$ close to that of the hemolymph, and yielded better results in comparison to those of FS 1 (Tables 1 and 2, Figs. 2 and 5). The successful association of phosphate buffer and sucrose (Suzuki \& Kondo, 1994; Michalik et al., 2004) is confirmed in the present work, in which this combination stabilized membranes of brown spider cells (Figs. 2 and 5).
Better results with nonionic osmolytes, such as sucrose or dextran, than $\mathrm{NaCl}$ have already been reported (Hayat, 1970).

As for FS 2, although it produced well-defined membranes, it was unsatisfactory in preserving mithocondria, in which some tissue swelling was observed.

Cacodylate - used as the buffer $(200 \mathrm{mM})$ in FS 4 and FS 5 (Table 1), with no osmolyte added - was nearly isosmotic to the brown spider hemolymph, and produced good results (Table 2; Figs. 3, 4, 6 , and 7). At this same concentration $(200 \mathrm{mM})$, phosphate buffer in FS 3 (Table 1) resulted in unsectionable tissue in these 3 preparations. Thus, cacodylate stands out as a better buffer than 
phosphate for spider testes (Hayat, 1970). Phosphate at a concentration of $100 \mathrm{mM}$, in association with $200 \mathrm{mM}$ sucrose, should be considered in studying brown spider tissues when use of toxic agents such as cacodylate is ruled out.

Use of glutaraldehyde with paraformaldehyde in FS 5 (Tables 1 and 2; Figs. 4 and 7) resulted in better preservation of the testes tissue, when compared to the results of glutaraldehyde alone (FS 4: Tables 1 and 2; Figs. 3 and 6), with which cytoplasmic organelles were visible, but the cytosol seemed coagulated. With FS 5, the cytosol appeared more uniform, and all membranes were perfectly preserved (Tables 1 and 2; Figs. 4 and 7). Glauert (1975) reported that the glutaraldehyde and paraformaldehyde combination results in better tissue preservation than either alone, because paraformaldehyde penetrates tissues much more rapidly and stabilizes the structures, while glutaraldehyde produces more permanent fixation. Our results with FS 4 and FS 5 on brown spider tissue confirm Glauert's observation.

The present results clearly evidenced that for optimal tissue preservation, attention should be paid to the extracellular fluid osmolality of animals being studied, and to the aldehydes added, buffer (cacodylate or phosphate), osmolytes added (sucrose or $\mathrm{NaCl}$ ), as well as to the total osmolality of the solution. The fixative formulas successfully used in the present work for ultrastructural studies of brown spider testes could also be tried for the tissues of other spider species, specially if their hemolymph is osmotically similar to that of Loxosceles intermedia.

Acknowledgments - This study was supported in part by the PIDCT/CAPES program. The osmometer was donated by DAAD (Deutscher Akademischer Austauschdienst). Eletronmicrographs were made at the Electron Microscopy Center of the Universidade Federal do Paraná (UFPR), Curitiba, Paraná, Brazil.

\section{REFERENCES}

FOELIX, R. F., 1996, Biology of the Spiders. Second Edition, Oxford University Press: New York.

GLAUERT, A. M., 1975, Biological Specimens. Stangeways ResearchLaboratory, Cambridge, North-Holland Publishing $\mathrm{CO}$, Amsterdam, Oxford.

GONÇALVES DE ANDRADE, R. M., LOURENÇO, W. R. \& TAMBOURGI., D. V., 2000, Comparison of the fertility between Loxosceles intermedia and Loxosceles laeta spiders (Araneae, Sicariidae). Journal of Arachnology, 28: 245-247.

HAYAT, M. A., 1970, Principles and Techniques of Electron Microscopy. Biological Applications, $1^{\circ}$ vol., Van Nostrand Reinhold Company, New York.

MICHALIK, P., DALLAI, R., GIUSTI, F. \& ALBERTI, G., 2004, The ultrastructure of the peculiar synspermia of some Dysderidae (Araneae, Arachnida). Tissue and Cell, 36: 477-460.

PLATNICK, N. I., 2004, The World Spider Catalog, version 4.5. American Museum of Natural History online at http:// research.amnh.org/entomology/spiders/catalog/index.html.

SILVEIRA, R. B., SANTOS-FILHO, J. B., MANGILI, O. C., VEIGA, S. S., GREMSKI, W., NADER, H. B. \& VON DIETRICH, C. P., 2002, Identification of proteases in the extract of venom glands from brown spiders. Toxicon, 40(6): 815-822.

SUZUKI, H, 1995, Fertilization occurs internally in the spider Achaearanea tepidariorum (C. Koch). Invertebrate Reproduction and Development, 28(3): 211-214.

SUZUKI, H. \& KONDO, A., 1994, The second maturation division and fertilization in the spider Achaeranea japonica (Bös. et Str.). Zoological Science, 11: 433-439.

UHL, G., 2000, Two distinctly different sperm storage organs in female Dysdera erythrina (Araneae: Dysderidae). Arthropod Structure \& Development, 29: 163-169. 